International Journal of Instruction e-ISSN: 1308-1470 • www.e-iji.net

Article submission code: 20201025162158

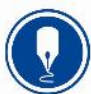

October $2021 \bullet$ Vol.14, No.4

p-ISSN: 1694-609X

pp. 451-462

Received: 25/10/2020

Revision: 25/03/2021
Accepted: 19/04/2021

OnlineFirst: 08/08/2021

\title{
Adaptations in Conservatories and Music Schools in Spain during the COVID-19 Pandemic
}

\section{Diego Calderón-Garrido}

Dr., Serra Húnter Fellow, Universitat de Barcelona, Spain, dcalderon@ub.edu

\author{
Josep Gustems-Carnicer \\ Prof., Universitat de Barcelona, Spain,jgustems@ub.edu
}

\section{Adrien Faure-Carvallo}

Universitat de Barcelona, Spain, adrienfaure@ub.edu

The lockdown imposed in Spain as a result of COVID-19 made it necessary to rethink educational processes. In this situation, digital technologies offered the most efficient solution by moving all teaching to an online format. The purpose of this study is to analyze the adaptations made in music schools and conservatories. To achieve this, an ad hoc questionnaire was designed and distributed, and resulted in a sample of 259 teachers. The results reveal a lack of training and structures that was reflected in the problems encountered by teachers with continuing instrumental classes, especially for ensembles. However, music theory classes were affected to a lesser extent. It was observed that musical performance was used to focus on the emotional aspects of students and their families.

Keywords: COVID-19, music education, music schools, conservatories, curricular adaptations

\section{INTRODUCTION}

COVID-19 is a disease that caused a global pandemic since the first half of 2020. Many countries adopted drastic lockdown measures to limit the reach of the virus and slow down the pandemic (Byass, 2020; Ceylan, 2020). As a result of the restrictions on freedom of movement, changes in daily life and education were also significant. At the end of April 2020, 1.5 billion children and young people in 195 countries were affected by school closures (Unesco, 2020). In Spain, the entire population was on lockdown and education institutions at all levels, including music schools and conservatories, were affected from mid-March to the end of the academic year.

This sudden change forced teachers to rethink their whole teaching methodology to alleviate the academic impact as much as possible. Online education represented the best way to continue the academic year. In this context, a distinction must be made between online education and "emergency remote education" provided in response to

Citation: Calderón-Garrido, D., Gustems-Carnicer, J., \& Faure-Carvallo, A. (2021). Adaptations in Conservatories and Music Schools in Spain during the COVID-19 Pandemic. International Journal of Instruction, 14(4), 451-462. https://doi.org/10.29333/iji.2021.14427a 
the situation caused by COVID-19 (Hodges et al., 2020). Both emergency remote teaching and online teaching ideally depend on digital technologies. However, online teaching is underpinned by an interest in the potential and benefits offered by digital technologies (Crawford, 2017). In emergency remote education, teachers are forced to reinvent themselves, without any previous preparation.

In a teaching format that uses digital technologies, special attention should be paid to the digital competence of educators. This competence is cross-disciplinary and closely linked to many skills required by citizens to ensure their participation in society (Ferrari, 2013). The digital competence of educators refers to two types of knowledge and skills: the ability to use digital technologies and skills relating to teaching and methodologies (Redecker, 2017).

This situation therefore tested teachers' knowledge and their use of educational technology. With respect to knowledge, the most widespread assessment model is the TPACK framework proposed by Mishra and Koehler (2006). This identifies three types of knowledge: content-related, pedagogical and technological. All three aspects must interact without any being overlooked, since they all influence each another. The SAMR model proposed by Puentedura (2015) examines the use of technology in teaching, as compared with past practice (Dammers, 2019). It proposes four levels to assess the use of digital technologies: substitution, augmentation, modification and redefinition. Substitution and augmentation are enhancement steps and represent the use of digital technologies in existing learning activities. Modification and redefinition are considered transformative because the learning activity is facilitated by technology to the point where the activity may not have existed or been possible prior to the availability of a particular technology. The ideal is to move from enhancement to transformative (Bauer $\&$ Mito, 2017). However, in the case of music education, some authors have pointed out that the norm is to remain at the lower levels, thus limiting the use of digital technologies (Calderón-Garrido et al., 2019).

In terms of the potential of digital technologies in music, the Technology Institute for Music Education (TI:ME, 2019) proposed six areas: 1) Electronic musical instruments (controllers and synthesizers). These instruments are used to edit timbres and create new or layered sounds, to carry out performances with recorded accompaniments, etc. 2) Electronic music production (digital audio, MIDI protocols, sound sequencing and design). This offers a wide range of possibilities for the classroom, such as editing and modifying audio and MIDI data, and using DAW software to explore and create different music styles and genres. 3) Computer music notation. This can be used to create or adapt the scores of all music to be used with students, to write and edit music data and link it to other types of music and productivity software, etc. 4) Music instruction software (educational software, internet-based learning, support tools, etc.). This includes all types of locally installed and downloaded resources from the web, and specially designed for the development of skills, such as reading music and listening. 5) Multimedia development. Multimedia authoring and distributing, different strategies for gathering, storing, repurposing and distributing analogue and digital media elements using the web, etc. 6) Productivity tools, classroom and lab resources. This includes the 
use of virtual spaces for storing and distributing data and other general applications, responsible and productive uses of social networks for communication, distribution of work, etc. (Calderón-Garrido et al., 2020).

In Spain, music education outside the school setting, at both amateur and professional level, takes place in music schools and conservatories. Although these centres started out with a different mission (Jefatura del Estado, 1992), their definition today is much more blurred and ambiguous (Jefatura del Estado, 2010). Nonetheless, it is possible to define four levels. The first, which is amateur in nature, does not lead to any type of qualification and is not regulated by examinations. The remaining three are official: elementary level with four years, professional level with six years and higher level with four years. The teachers of instrumental subjects in these official studies are graduates from conservatories and, in the case of theory subjects, may also be university teaching staff (Jefatura del Estado, 2010). With respect to teaching aimed at amateur musicians, there are no regulations. In general, conservatories traditionally lean towards official education more so than music schools.

In terms of the digital competence of educators at Spanish conservatories, Palau et al. (2019) concluded that it was generally very low, regardless of the instrument taught or the gender of the teaching staff, although younger teachers obtained slightly higher results. In the case of Spanish music schools, the studies conducted so far have only addressed proposals for activities and resources, without measuring the results obtained or the educators' digital competence.

In short, the situation caused by COVID-19 has made it necessary to rethink the music education offered at these centres and to reflect on learning processes. No previous study has analysed the changes caused by the pandemic in music schools and conservatories, so this research seeks to ascertain how music teachers at Spanish music schools and conservatories conducted lessons during the lockdown. Thus, the aim is to identify the means and frequency with which teachers communicated with students and to determine the content that was taught and assessed and the adaptation measures that were needed to achieve this.

\section{METHOD}

To fulfil the objective, an online ad hoc questionnaire was created and administered. The questionnaire was developed in accordance with Godet's SWOT analysis (2000), applied to music education content in a situation of emergency remote teaching in music schools and conservatories. It also contained questions on the sociodemographic characteristics of respondents.

The questionnaire was designed by a panel of five music education experts using the Delphi method (Somerville, 2008). The respondents answered three rounds of test questionnaires, and the responses were compiled and shared with the group after each round. In this process, a Cohen's kappa value of .90 was obtained. The final questionnaire contained 29 questions that addressed three aspects (sociodemographic characteristics; communication between teachers and students; teaching and assessment of music content). The questionnaire consisted of dichotomous questions, multiple- 
choice questions and open-ended questions. It was administered using the Formsite platform and a 21-day period was established for responses. The sample was obtained through the email addresses of the music schools and different social networks. This ensured that the sample encompassed the whole of Spain.

The results were gathered and analysed using the IBM Statistical Package for the Social Sciences program, version 21.0. In addition to the usual statistics for a basic analysis, the Mann-Whitney and Kruskal-Wallis tests were used. Prior to this, the KolmogorovSmirnov or Shapiro-Wilk normality tests were performed on the sample as required. In addition, Levene's test was used to check the equality of variance. For the answers to the open questions, a qualitative analysis was carried out using ATLAS.Ti software, version 1.5.2.

After the final count, incomplete responses $(n=12)$ and responses from teachers who had not had any contact with their students $(n=4)$ were removed. Thus, the final sample consisted of 259 teachers: 136 women $(52.5 \%)$ and 123 men $(47.5 \%)$. The mean age of the participants was 44.81 years $(\mathrm{SD}=9.684)$. Of these, $69.1 \%$ worked in a music school, $18.5 \%$ in a conservatory and $12.4 \%$ in both types of centre. The teaching staff had a mean of $20.85(\mathrm{SD}=9.647)$ years of teaching experience.

\section{FINDINGS}

In terms of the teachers who were able to stay in contact with their students, the majority (78.9\%) searched for the application best suited to their needs, $19.6 \%$ used applications designed for virtual meetings, provided by the centre itself, and $1.5 \%$ maintained contact through phone calls.

With respect to frequency of contact, most communicated with their students once a week $(49.8 \%)$, followed by a couple of times a week $(30.1 \%)$, daily $(16.6 \%)$, biweekly $(2.7 \%)$ and monthly $(0.7 \%)$. With respect to coordination between teaching staff, $74.5 \%$ said they had coordinated with the others.

In terms of how they had learned to use the various platforms for communicating with students, the majority taught themselves $(72.5 \%)$, and the remainder said that they had learned through talking to colleagues $(17.6 \%)$, received training from the centre $(8.6 \%)$ or received training from the public authorities $(1.4 \%)$. Regarding the content taught, the results are shown in Table 1.

Table 1

Content taught

\begin{tabular}{|c|c|c|c|c|c|}
\hline \multirow[t]{2}{*}{ Type of content } & & \multirow[t]{2}{*}{ Regularly teaches } & \multicolumn{2}{|c|}{$\begin{array}{l}\text { Was able } \\
\text { to continue teaching }\end{array}$} & \multirow{2}{*}{$\begin{array}{l}\text { Differences } \\
\text { according } \\
\text { to the centre }\end{array}$} \\
\hline & & & Yes & No & \\
\hline \multirow{2}{*}{ Instrumental class } & $\mathrm{n}$ & 220 & 25 & 195 & $X^{2}{ }_{2}=3.369$ \\
\hline & $\%$ & $84.9 \%$ & $11.4 \%$ & $88.6 \%$ & $p=.186$ \\
\hline \multirow{2}{*}{ Theory class } & $\mathrm{n}$ & 101 & 81 & 20 & $X^{2}{ }_{2}=2.936$ \\
\hline & $\%$ & $39 \%$ & $80.2 \%$ & $19.8 \%$ & $p=.230$ \\
\hline \multirow{2}{*}{$\begin{array}{l}\text { Instrumental } \\
\text { ensemble class }\end{array}$} & $\mathrm{n}$ & 132 & 37 & 95 & $X^{2}{ }_{2}=2.826$ \\
\hline & $\%$ & $51 \%$ & $28 \%$ & $72 \%$ & $p=.243$ \\
\hline
\end{tabular}


Regarding instrumental classes, most made some kind of modification, such as Respondent 108, who taught "through the same virtual web service I had already been using for three years at my music school, but with videoconferencing as a new tool". However, some teachers were able to continue with the normal schedule, as with Respondent 5, who commented "the entire programme had already started and an audition was scheduled for May, so we carried on as if the recital was going ahead".

Almost all teachers used various videoconferencing applications to continue teaching instrumental classes, in addition to including recordings as accompaniments. This was the case with Respondent 218, who stated that he had "demonstrated technical exercises with his home piano and asked students to copy him, in addition to sending recordings of piano four hands playing one of the voices and asking the students to play the other voice over it". However, one of the general complaints was that "certain concessions had to be made, especially in terms of sound and positioning, given the quality of video calls and the age of the students" (Respondent 20).

In any case, it was clear that the teachers had made an effort to organize classes and adapt to the situation, as summed up by Respondent 126 when he stated that he had "reorganized the students and grouped them by levels instead of by programmes, and reestablished objectives and activities". Sometimes, these adaptation measures were due to academic regulations, as indicated by Respondent 35 who "generally did not really need to adapt the curriculum", although he did make changes "due to bureaucratic procedures imposed by the centre's management team".

Regarding the assessment of instrumental classes, some respondents $(n=8)$ directly stated that they would not assess them. The teachers who did assess their students attached greater importance to the students' attitudes, as reported by Respondent 20, who said:

We won't assess the students, since the teachers have agreed to it, but this third term will be considered a term for monitoring. That means we'll assess their attitude, their ability to adapt and their commitment. Therefore, we'll focus on values rather than knowledge, despite the fact that lower-quality material might have been submitted in some cases.

Some teachers decided to assess students through the musical works they had studied, albeit asynchronously, as indicated by Respondent 201, who applied "continuous assessment of the assignments submitted by the students and/or audio".

Regarding theory classes, adaptation measures involving both synchronous and asynchronous communication were very common, as summarized by Respondent 3 whose teaching methods involved:

...giving explanations via videoconference and receiving assignments by email in Sibelius or PDF format, returning assignments with corrections and comments, giving explanations and instructions via WhatsApp voice messages, and responding to queries from students by telephone or WhatsApp at any time of day.

In some cases, teachers made use of digital technologies when communicating with students, albeit with some modifications, such as Respondent 81 , who taught "through the same virtual web service I had already been using for three years at my music 
school, but with videoconferencing as a new tool". In any case, it was impossible to monitor students in the same way as before, especially younger students, as confirmed by Respondent 107, who said, "with basic-level students, I sent assignments every week, but very few were returned". Nevertheless, with respect to older students, especially those who had to pass a level ${ }^{1}$, attempts were made to maintain the same working pace. For example:

With respect to students who had to pass the entrance exam for the conservatory, we carried on doing mock exams from previous years and working on content they hadn't studied yet. With professional level students, we focused on analysis and listening through activities based on films and questions in Kahoot (Respondent 201).

In any case, there were clear failings caused by the move to online teaching. These were due to the software chosen, the teachers' digital competence or a combination of both, as was the case with Respondent 117, who acknowledged "what I found most difficult was not being able to see all my students' faces at the same time and not having a blackboard to improvise explanations and answers". In addition, the teachers had to cope with hardware-related limitations, as confirmed by Respondent 12, who said "it was very stressful, since I was always worried about internet connectivity issues and my own computer breaking down without any administrative support".

Moreover, some teachers expressed how difficult the adaptation process was:

It was really hard. I spent hours recording rhythmic lessons, tuned with piano accompaniments, explaining how it should be done and giving guidelines, explaining it with theory videos and sending photos with corrections (Respondent 149).

With respect to assessments, participation and follow-up of classes were taken into account, but preference was given to grades from previous terms, as summarized by Respondent 46, who planned to base his assessment on:

...the assignments submitted by students, attendance and the interest shown in our interactions, and whether the assignments responded to the explanations and instructions given. In principle, students will get the grade they received in the first term, which will be combined with their work during the lockdown. Only students who want to improve that grade will have to sit exams.

In any case, some teachers expressed their concern about the differences between the students, such as the case of Respondent 172, who stated that he would "take the personal circumstances of each student into account".

With respect to instrumental ensemble classes, this was the area that underwent most modifications due to the technological limitations and latency issues of the various videoconferencing platforms. In this regard, the teachers were categorical in their responses:

I changed the objective for the academic year. We couldn't play together, but we were able to play separately and put music and videos together. We also took the opportunity to focus on

\footnotetext{
${ }^{1}$ In Spain, this refers to moving up a level in music studies; in other words, from elementary to professional level or from professional to higher level.
} 
the context and functions of musical training and the repertoire. The work centred more on theoretical aspects than on playing together (Respondent 26).

In this regard, audiovisual skills were key, as revealed by Respondent 94, who commented that "we made multiscreen video montages that successfully engaged the students", and Respondent 165, who said, "they went from giving group performances to creating audiovisual materials in groups".

In any case, there is little doubt that the instrumental ensemble was the biggest victim of the lockdown, since "ensembles and chamber music involved more individualized exercises" (Respondent 248). This sentiment was also reflected in the following statement:

At the beginning of lockdown, I kept in weekly contact with my students who had band classes. They couldn't play together, but they listened to each other performing individually and gave each other feedback. Given that these students would have to sit an exam for access to the professional level, I ended up deciding to use that weekly hour to tutor them on the works in the exam, instead of continuing with the band repertoire (Respondent 40).

With respect to assessments, given that teachers were not able to keep up the usual pace of classes, one teacher said, "I assessed the face-to-face work they had completed up until March" (Respondent 219). Despite this, some assessments were carried out on a continuous basis by taking account of the work completed during the lockdown, as was the case of Respondent 226, who said, "I used the audio recordings and multiscreen videos to assess my students".

In this regard, it was clear that assessments were adapted to each student's situation:

I took a personalized approach to assessments and considered not only students' instrumental results, but their actual potential given their circumstances during the lockdown (Respondent 162).

A total of $51.1 \%$ were able to focus on emotional aspects in their classes during the lockdown. There were statistical differences according to the type of centre $\left(X^{2}{ }_{2}=\right.$ 9.901; $p=.011$ ), with those working in music schools much more likely to have addressed emotional aspects $(57.8 \%)$ than those working in conservatories or both types of centre $(45.8 \%$ and $29 \%$, respectively). There were also statistical differences according to gender $(z=-3.694 ; p<.001)$, since women were more likely than men to focus on emotional aspects $(62.7 \%$ vs $37.6 \%)$.

In some cases, teachers took a more playful approach to music, as was the case with Respondent 2, who said that "the students had a higher workload than in face-to-face classes, so I recommended that they play for fun for a while. I told them to play whatever they wanted and not just the pieces they had been assigned to work on". Thus, the teachers acknowledged the role played by music and art during the lockdown, since it had "helped both musicians and society as a whole to cope with the lockdown. We've seen it every day. All of society has relied on music at the most challenging moments" (Respondent 187). Without question, the situation provided a source of inspiration for many students, as revealed by Respondent 95, who said, "We focused on creation based on texts and drawings produced by the youngest kids to express their daily emotions 
during the pandemic". There is little doubt that, during this health crisis, "music offered our students an escape from the reality of the situation" (Respondent 257).

\section{DISCUSSION}

During the lockdown caused by the global pandemic, emergency remote education took on a central role. Nevertheless, as borne out by this research, the communication channel sometimes failed, which made it impossible to continue classes as normal. As reported by Morgan (2020), this has been a common feature in all countries and disciplines due to internet access issues experienced by both teachers and students.

In the case of teachers who were able to continue working, most searched for the application that best suited their needs. In this regard, the lockdown involved exploiting the resources and platforms that worked for them, even when they had not been designed for educational purposes (World Bank, 2020). With respect to training on these resources, our research was consistent with a study carried out by the authors (2020) among music teachers, in this case at university level.

In these interactions between teachers and students, different frequencies and habits were established, which involved both synchronous and asynchronous communication (Yoon, 2019). This allowed both teachers and students to access the different resources when it was most convenient for them (Tria, 2020). Thus, some of the benefits of technology were uncovered during the pandemic, and allowed students to access knowledge when it best suited them (Toquero, 2019).

With respect to the music content taught during the lockdown, the teachers at conservatories and music schools experienced the same latency issues described by Daubney and Fautley (2020). This meant that content in which sound, synchrony and quality played a central role was hardest hit. For the most part, therefore, instrumental and ensemble classes were discontinued in both music schools and conservatories.

With regard to instrumental classes, the use of videoconferencing was crucial for those who were able to continue teaching. However, an analysis of the teachers' responses indicates that this was limited to replacing face-to-face classes. Thus, according to the SAMR Model (Puentedura, 2015), this use represented the lowest level of technology integration, given that much of the potential of these digital technologies was squandered.

Regarding ensemble classes, the responses revealed adaptation measures in which the asynchronous use of audiovisual resources took on a leading role. The most common approach involved viewing videos prepared by teachers or creating multi-camera montages. This was common in all countries (National Association for Music Education, 2020 ) and across all disciplines (Guo \& $\mathrm{Li}, 2020$ ). In this regard, pre-recorded videos already represented a very common resource in music education (Bautista et al., 2019).

With respect to music theory, our research reveals that this was the least affected area. However, in many cases, the results depended on teachers' prior knowledge and their attitude towards ICTs. This, as explained by Ju et al. (2016), is crucial for achieving good results when using digital technologies as a facilitator in educational processes. 
On a generic level, the pandemic gave rise to a collaborative spirit among music teachers around the world, who shared their resources in different ad hoc repositories such as \#CanDoMusic (2020). Even associations such as the National Association of Music Merchants issued guidelines on how to prevent a fresh outbreak, including instructions for social distancing in music classrooms (Dale, 2020).

With respect to the assessment of content, the research revealed that most teachers resorted to using the grades previously obtained by students, with or without taking account of their attitude towards the knowledge acquired during the lockdown. This was a common theme in all countries (Daubney \& Fautley, 2020).

In any case, with respect to the content taught in instrumental, ensemble and music theory classes, it should be noted that no statistical differences were detected based on age or gender. This finding is at odds with studies by Lamschestein (2010) on the generation gap and Almerich et al. (2005) on the gender gap in the use of ICTs.

With regard to emotional aspects, the pandemic and lockdown gave rise to both negative emotions, caused by uncertainty and a fear of losing loved ones (Posner et al., 2005), and positive emotions, as a result of reflection and family time (Brooks et al., 2020). Using music to manage the negative emotions caused by COVID-19 has been shown to offer clear benefits in terms of reducing stress and improving well-being, as reported by Giordano et al. (2020). Thus, the statistical differences observed may have been due to the age of the students, given that students at music schools are younger and emotionbased activities are more likely to be carried out with younger students. In any case, it was encouraging to observe how students were able to use music in a productive and not solely responsive way to cope with daily life during the lockdown.

\section{CONCLUSIONS}

In short, the situation caused by COVID-19 sped up the developments that were already under way in virtual music teaching, such that many teachers, even if only due to current needs, explored the potential offered by online teaching (He, 2020). In this respect, this study detected a lack of training among teachers and a shortage of resources that must be addressed as soon as possible. No one knows what the future holds for music education, but one thing is clear: it will be different. However, as has occurred with music consumption and the shift in preferences towards visual formats (such as YouTube) at the expense of recorded music (Sim et al., 2020), the lockdown has given rise to new recruits eager to receive musical training after seeing how teachers used social networks to teach musical instruments (Botstein, 2020). Undoubtedly, a prospective of this research is to analyze if the changes made have been successful and if they have lasted in time. Likewise, it is suggested to investigate whether the training of future music teachers after COVID-19 includes more education in digital technology to solve future problems.

In conclusion, COVID-19 has served as a catalyst for educational change, for rethinking the what, how and where of the teaching and learning process (Zhao, 2020). To achieve this, digital competence is key. Our results indicate that teachers in Spanish music schools and conservatories must further develop these skills to effectively tackle future changes. 


\section{REFERENCES}

\#CanDoMusic (2020). \#CanDoMusic: Teaching music during coronavirus (COVID19). https://www.candomusic.org/\#top

Almerich, G., Suárez, J., Orellana, N., Belloch, C., Bo, R., \& Gastaldo, I. (2005). Diferencias en los conocimientos de los recursos tecnológicos en profesores a partir del género, edad y tipo de centro. Revista ELectrónica de Investigación y EValuación 11(2). http://www.uv.es/RELIEVE/v11n2/RELIEVEv11n2_3.htm

Educativa,

Bauer, W. I., \& Mito, H. (2017). ICT in Music Education. In A. King, E. Himonides \& S. A. Ruthmann (eds.). The Routledge Companion to Music, Technology, and Education (pp. 91-102). New York: Routledge.

Bautista, A., Tan, C., Wong, J., \& Conway, C. (2019). The role of classroom video in music teacher research: A review of the literature. Music Education Research, 21(4), 331-343. https://doi.org/10.1080/14613808.2019.1632278

Botstein, L. (2020). The Future of Music in America: The Challenge of the COVID-19 Pandemic. The Musical Quarterly, 102(4), 351-360. https://doi.org/10.1093/musqtl/gdaa007

Brooks, S.K., Webster, R.K., Smith, L.E., Woodland, L., Wessely, S., Greenberg, N., \& Rubin, G. J. (2020). The psychological impact of quarantine and how to reduce it: rapid review of the evidence. Lancet, 395, 912-920. https://doi.org/10.1016/S01406736(20)30460-8

Byass, P. (2020) Eco-epidemiological assessment of the COVID-19 epidemic in China, January-February 2020. Global Health Action, 13. https://doi.org/10.1080/16549716.2020.1760490

Calderón-Garrido, D., Cisneros, P., García, I., \& de las Heras, R. (2019). La tecnología digital en la educación musical: una revisión de la literatura científica. Revista Electrónica Complutense De Investigación En Educación Musical - RECIEM, 16, 4355. https://doi.org/10.5209/reciem.60768

Calderón-Garrido D, Gustems-Carnicer J, \& Carrera X. Digital technologies in music subjects on primary teacher training degrees in Spain: Teachers' habits and profiles. International Journal of Music Education. August 2020. https://doi.org/10.1177/0255761420954303

Ceylan, Z. (2020). Estimation of COVID-19 prevalence in Italy, Spain, and France. Science of The Total Environment, 729, 138817. https://doi.org/10.1016/j.scitotenv.2020.138817

Dale, E. (2020). COVID-19 \& Social Distancing Music Making Resources. https://www.namm.org/playback/advancing-music-making/covid-19-social-distancingmusic-making-resources 
Dammers, R. J. (2019). The role of technology in music teacher education. In C. Conway, K. Pellegrino, A. M. Santaley \& C. West (eds.). The Oxford Handbook of Preservice Music Teacher Education in the United States (pp. 365-376). Oxford: Oxford University Press.

Daubney, A., \& Fautley, M. (2020). Editorial Research: Music education in a time of pandemic. British Journal of Music Education, 37(2), 107-114. https://doi.org/10.1017/S0265051720000133

Ferrari, A. (2013). DIGCOMP: A Framework for Developing and Understanding Digital Competence in Europe. Sevilla: European Commission. Joint Research Centre. Institute for Prospective Technological Studies.

Godet, M. (2000). The Art of Scenarios and Strategic Planning: Tools and Pitfalls. Technological Forecasting and Social Change, 65(1), 3-22. https://n9.cl/i2pg

Guo, B., \& Li, H. (2020). Guidance Strategies for Online Teaching during the COVID19 Epidemic: A Case Study of the Teaching Practice of Xinhui Shangya School in Guangdong, China. Science Insight Education Frontiers, 5(2), 547-551. https://doi.org/10.15354/sief.20.rp020

He, Y. (20201). Research on Online Teaching of Music Performance Based on Diversification and Intelligence-Take the Online Music Teaching during the COVID-19 as an Example. In 2020 International Conference on E-Commerce and Internet Technology (ECIT) (pp. 193-196). https://doi.org/10.1109/ECIT50008.2020.00050

Hodges, C., Moore, S., Lockee, B., Trust, T., \& Bond, A. (2020). The Difference Between Emergency Remote Teaching and Online Learning. Educause Review. https://n9.cl/5o8n

Jefatura del Estado (1992). Orden de 30 de julio de 1992 por la que se regulan las condiciones de creación y funcionamiento de las Escuelas de Música y Danza. Boletín Oficial del Estado, 202, 29396-29399. https://www.boe.es/eli/es/o/1992/07/30/(5)

Jefatura del Estado (2010). Real Decreto 303/2010, de 15 de marzo, por el que se establecen los requisitos mínimos de los centros que impartan enseñanzas artísticas reguladas en la ley Orgánica 2/2006, de 3 de mayo, de Educación. Boletín Oficial del Estado, 86, 1-15. https://www.boe.es/buscar/pdf/2010/BOE-A-2010-5662consolidado.pdf

Lamschtein, S. (2010). Las TICs y la brecha generacional. Montevideo: Observatic. http://dspace.mides.gub.uy:8080/xmlui/handle/123456789/628

Mishra, P., \& Koehler, M. (2006). Technological pedagogical content knowledge: A Framework for Teacher knowledge. Teachers College Record, 108(6), 1017- 1054. https://n9.cl/7njs

Morgan, H. (2020). Best Practices for Implementing Remote Learning during a Pandemic. The Clearing House: A Journal of Educational Strategies, Issues and Ideas, 93(3), 134-140. https://doi.org/10.1080/00098655.2020.1751480 
National Association for Music Education (2020). NAfME COVID-19. https://nafme.org/covid-19/

Palau, R., Usart, M., \& Ucar, M. (2019). La competencia digital de los docentes de los conservatorios. Estudio de autopercepción en España. Revista Electrónica de LEEME, (44), 24-41. https://doi.org/10.7203/LEEME.44.15709

Posner, J., Russell, J. A., \& Peterson, B. S. (2005). The circumplex model of affect: An integrative approach to affective neuroscience, cognitive development, and psychopathology. Development and psychopathology, 17(3), 715-734. https://doi.org/10.1017/S0954579405050340

Puentedura, R. R. (2015, October 14). SAMR: A brief introduction [Blog post]. https://n9.cl/oemh

Redecker, C. (2017). European framework for the digital competence of educators: DiGiCompEdu. Publications Office of the European Union.

Sim, J., Cho, D., Hwang, Y., \& Telang, R. (2020). Virus Shook the Streaming Star: Estimating the COVID-19 Impact on Music Consumption. SSRN. https://doi.org/10.2139/ssrn.3649085

Somerville, J. A. (2008). Effective Use of the Delphi Process in Research: Its Characteristics, Strengths and Limitations. Corvallis (Oregon). https://n9.cl/0yze

TI:ME. (2019). Areas of Pedagogical Skill and Understanding (TAPSU). Retrieved from https://ti-

me.org/index.php?option=com_content\&view=article \&id=2257\&Itemid=1606

Toquero, C. M. (2020). Emergency remote education experiment amid COVID-19 pandemic. IJERI: International Journal of Educational Research and Innovation, (15), 162-172. https://doi.org/10.46661/ijeri.5113

Tria, J. Z. (2020). The COVID-19 Pandemic through the Lens of Education in the Philippines: The New Normal. International Journal of Pedagogical Development and Lifelong Learning, 1(1). https://doi.org/10.30935/ijpdll/8311

Unesco (2020) 1.3 billion learners are still affected by school or university closures, as educational institutions start reopening around the world, says UNESCO. Online at https://en.unesco.org/news/13-billion-learners-are-still-affected-school- universityclosures-educational-institutions Accessed 04/20

World Bank (2020). Remote Learning, Distance Education and Online Learning DUring the COVID19- Pandemic: A Resource List By the World Bank's Edtech Team. Washington, D.C.: World Bank Group. https://tinyurl.com/yxam7vq8

Ju, Y., Yon, K., \& Hee, N. (2016). The effects of secondary teachers' technostress on the intention to use technology in South Korea. Computers \& Education, 95, 114-122. https://doi.org/10.1016/j.compedu.2015.12.004

Zhao, Y. (2020). COVID-19 as a catalyst for educational change. Prospects. https://doi.org/10.1007/s11125-020-09477-y 